\title{
Measuring the Managerial Efficiency of Insurance Companies in Saudi Arabia: A Data Envelopment Analysis Approach*
}

\author{
Mohammad NAUSHAD ${ }^{1}$, Mohammad Rishad FARIDI ${ }^{2}$, Shaha FAISAL ${ }^{3}$ \\ Received: March 29, 2020 Revised: April 17, 2020 Accepted: May 01, 2020
}

\begin{abstract}
This paper applies the Data Envelopment Analysis (DEA) to compute the managerial efficiency of 30 insurance companies listed on the Saudi stock exchange for the duration of four years from 2015 to 2018 . The companies taken as a sample of study included both conventional and Takaful insurance companies. The insurance sector of KSA is one of the largest sectors in the country, contributing a substantial percentage in the non-oil economy. Efficiency measurement and evaluation will provide a venue to introspect and benchmark frontiers to the sector. In the present study, we have utilized the basic Banker Charnes Cooper and Charnes Copper Rhodes models of DEA. Two inputs, namely, general \& administrative expenses and policy \& acquisition costs, and two outputs (Net premium earned and Investment Income \& other incomes) were taken for efficiency calculations. The final outcomes of the study reveal that a good number of insurance companies operating in KSA are found to be efficient on managerial efficiency scale. Three firms remain the leader on the frontier of the managerial efficiency. And no company found with zero (0) efficiency or a negative efficiency. It is expected that the outcome of the study will provide benchmarks to managers and a road map to further improvement.
\end{abstract}

Keywords : DEA, Managerial Efficiency, Insurance Sector, Saudi Arabia.

JEL Classification Code: G22, G14, C67

\section{Introduction}

The Saudi Insurance sector is considered highly competitive in nature. There are thirty-three listed companies in KSA. Out of that six companies are Takaful companies,

*This publication was supported by the Deanship of Scientific Research at Prince Sattam Bin Abdulaziz University.

${ }^{1}$ First Author, Assistant Professor, Management Department, College of Business Administration, Prince Sattam Bin Abdulaziz University, Alkharj, Kingdom of Saudi Arabia [Postal Address: P.O. Box 165, Alkharj, ArRiyadh Province, 11942, Saudi Arabia] Email: meetnaushad@gmail.com

${ }^{2}$ Corresponding Author, Assistant Professor, Marketing Department, College of Business Administration, Prince Sattam Bin Abdulaziz University, Alkharj, Kingdom of Saudi Arabia (KSA). Email:m.faridi@psau.edu.sa; n.mohammad@psau.edu.sa ${ }^{3}$ Assistant Professor, HRM Department, College of Business Administration, Prince Sattam Bin Abdulaziz University, Alkharj, Kingdom of Saudi Arabia (KSA). Email: s.shah@psau.edu.sa

(c) Copyright: The Author(s)

This is an Open Access article distributed under the terms of the Creative Commons Attribution Non-Commercial License (http://Creativecommons.org/licenses/by-nc/4.0/) which permits unrestricted noncommercial use, distribution, and reproduction in any medium, provided the original work is properly cited. offering Sharia' principles based products, and twenty-six are conventional companies (Almulhim, 2019). Likewise, the insurance activities in KSA remain relatively new, as the sector has not achieved its full potential. Like the insurance industry in other parts of world, KSA insurance sector has also witnessed several regulatory changes and subsequently galloped the terrain of growth. With the advent of foreign players in the market, the survival of existing players is highly dependent upon the successful execution of their competitive strategies. As a rule of thumb the effective formulation and execution of competitive strategy are grounded upon the managerial capabilities, competitive intelligence and economies of advantage and disadvantages, etc. For strategic reasons organizations are usually interested in knowing self and competitors' efficiency level. Efficiency measurement provide the way to compare the relative benefits occurred from the use of varying or similar inputs and outputs (Chen, 2007; Choi \& Cho, 2019). Efficiency of an organization is reflected in the ability of converting the input into output by an effective production function.

Efficiency measurement has been an important focus point for the banking sector around the world (Yang \& Liu, 2012). However, in the last decade, researchers have 
also focused on measurement of efficiency in the insurance sector (Akhtar Muhammad, 2018; Masud, Rana, Mia, \& Saifullah, 2019; Al-Amri, 2015; Almulhim, 2019; Barros et al., 2014; Eling \& Luhnen, 2010; Hwang \& Tong-Liang, 2006; Mandal, 2014; Nourani et al., 2017) as well. Most recent studies in KSA insurance sector (Akhtar Muhammad, 2018; Almulhim, 2019; Benyoussef \& Hemrit, 2019; Hemrit, 2020) evaluated the general, pure and technical efficiencies of insurance companies operated in the kingdom. But it seems that managerial efficiencies of insurance firms still need to be explored. This paper aims to evaluate the managerial efficiency of various firms listed and operated in the Saudi insurance sector. The study will cover only the listed firms registered at Tadawul, the Saudi Arabian stock exchange. The efficiency will be calculated by utilizing the most prominent efficiency measurement tools, i.e., DEA. We have applied the basic models (BCC \& CCR) of DEA. The paper includes the following sections. Section 2 will review the existing literature available on the insurance industry in general and the insurance industry in KSA in particular. Section 3 will specify the methodology adopted. Section 4 will present the results. Section 5 will provide a discussion upon the results derived from the analysis. And Section 6 will summarize the findings and conclude with a note on future scope for research.

\section{Literature Review}

The efficiency measurement of any production function of business is highly significant for decision-making, further improvement and survival as a whole. The earlier methods for efficiency measurement found in literature utilizes the ratio analysis alone, or with combination of other analytical tools such as Probit, Logit and multiple regression, etc. Assuredly, ratio analysis has certain limitations and is unable to provide the accurate and actual picture of companies' performance efficiencies. Studies like, Charnes et al. (1978) and Banker et al. (1984) which came out with a novel approach called Data Envelopment Analysis (DEA) to calculate the efficiencies of decision making units (DMUs). Initially, DEA used to be considered as the efficiency measurement tools for banks only (Shyu \& Chiang, 2012). But later, it has been applied on diverse industries and sectors for efficiency measurements and benchmarking. After the banking sector, the activity highly related to banking production function is the insurance sector. Kaffash et al. (2019) in their study found that during the period of 1992 to 2018 there were 132 studies on the insurance sector. Studies reviewed in the said paper applied DEA to calculate the efficiency of firms from various backgrounds, with multiple inputs and outputs. There are other studies in literature (Borges et al., 2008; Cummins \& Weiss, 2013; Ilyas Ashiq, 2019; Mandal, 2014), which calculated the efficiency of insurance companies by adopting DEA as tool for efficiency measurement.
However, the literature available focuses only on the production function of the insurance industry, though a little attention has been given to the managerial efficiency of insurance firms. Managerial efficiency could be understood as the ability of manager in utilizing the organizational resources for converting the input into the output and ultimately in achieving the organization' goal (Avkiran \& Rowlands, 2008; Hwang \& Tong-Liang, 2006; An, Ryu, \& Yoon, 2020). Nevertheless, several qualitative and quantitative proxies explore the measurement of managerial efficiency in literature. But undoubtedly, DEA-based studies provide the precise way to understand the managerial efficiency, as the calculations rely upon the defined inputs and outputs. However, DEA vectors are not universal. It varied from industry to industry, e.g., Chen, C. F. (2007) who applied DEA on managerial efficiency of hotels in Taiwan by utilizing price of labor, material, food and beverages as input variables and total revenue of hotels as output. Similarly, Yang and Liu (2012) applied the network DEA model by taking personnel cost, operation cost and interest cost as input and deposits as output in stage one while interest income, fee income and fund transfer income as output to stage two. Pacheco and Fernandes (2003) analyzed the managerial efficiency of Brazilian airports by five outputs (domestic passengers; cargo plus mail; operating revenue; commercial revenue; other revenues) and three inputs (average number of employees; payroll, and operating expenses). Agasisti (2014) measured the managerial efficiency of Italian schools by applying the two-stage DEA model on two inputs (students teacher ratio and expenditure per students) and one output (marks scored by students in two different subjects).

As far as the managerial efficiency of insurance sector is concerned, it is different from other sectors in a way that the production function of insurance industry is different from other sectors (Rahman, 2018). The efficiency of insurance sector depends upon the effective utilization of money received as premium and optimization of marketing regime activities. Therefore, production function of insurance industry stands on two pillars: (i) marketing activities and investment activities (Hwang \& Tong-Liang, 2006). Thus, the factors that determine the managerial efficiency of insurance companies resolves around the organizational activities that involves conversion of investment in various resources to output in the form of achievement of objectives.

Studies mentioned in the literature of managerial efficiency of insurance firms cover these aspects discussed above. The most prominent study (Hwang and Tong-Liang, 2006) on managerial efficiency applied a two-stage DEA upon twenty-four insurance companies listed in Taiwan. The study utilized two inputs (Business and administrative expenses, and commission and acquisition costs) and two outputs (direct written premium and reinsurance premium received). Rao (2010) investigated the managerial efficiency 
of listed firms in UAE. The study utilized the two inputs (administrative and general expenses, and equity and change in legal reserves) and two outputs (rate of return on investments and liquid asset to total liabilities ratio). Nourani et al. (2017), along with other measures, also calculated the managerial efficiency of 30 insurance companies of Malaysia during the period of 2008-2012. The study took three inputs (managerial expenses, total assets and staff costs) and two outputs (incurred claims plus additions to reserves and investment assets).

So far as research on Saudi insurance sector is concerned, there are studies like Akhtar Muhammad (2018), which find the efficiency of insurance companies in KSA by taking multiple inputs, outputs and using DEA during the period of 2010-2014. Almulhim (2019) analyses the performance of conventional insurance v/s Takaful companies in KSA. The study utilizes the two-stage DEA by adopting the three inputs, namely, equity, general and administrative expenses, and net claims incurred; and two outputs, namely, investment and management fee income and net earned premium. A similar kind of study was also made by Benyoussef and Hemrit (2019), but this study utilizes the one-stage DEA. While and Hemrit (2020) investigated the determinates of financial performance of non-cooperative and Saudi Takaful companies during the period of 2013-2017.

Similarly, there are studies like AlKhathlan and Malik (2010); Haque and Sultan (2019); Ali and Tausif (2019), Naushad (2019a, 2019b); Naushad and Malik (2015); and Sulphey and Naushad (2019) that also explored the services quality, profitability, and efficiency analysis of financial insurance and banking sectors in KSA. But no study, to the best of this researcher's knowledge, is available which explores the managerial efficiency of insurance companies in KSA using DEA.

Therefore, the present study will has a two-fold objective: (i) to calculate the managerial efficiency of the insurance companies in KSA and (ii) to identify the benchmark for other firms for the given period. Thus, to achieve the objectives stated and carry out the efficiency study two inputs and two outputs have been identified: Input: 1- General and administration expenses. 2- Policy and acquisition costs. Output: 1- Net premium earned. 2- Investment Income and other incomes.

\section{Research Methodology}

The target DMUs for this study consists of all the listed insurance companies in Tadawul, the stock exchange of Saudi Arabia. Overall, there are 33 companies listed in Tadawul, whereas the data required for our study was available only for 30 companies. Therefore 30 companies have been selected for the final analysis. These 30 companies are denoted by the independent decision-making units (DMUs) in our study.
Four-year data, from 2015 to 2018, was considered for analysis. The data has been collected from Tadawul website, i.e. www.tadawul.com, but wherever it is not available, annual reports of individual companies have been consulted. Since the nature of data is secondary, only the audited figures available in the public domain have been considered.

As discussed in the literature review, the highlyrecommended tool for efficiency studies is the DEA. We consider the basic DEA models (Banker Charnes Cooper (BCC) and Charnes Copper Rhodes (CCR) propounded by Banker et al. (1984) and Charnes et al. (1978) respectively) for the current study.

The basic model of DEA propounded by Charnes et al. (1978) suggests that a DMU' $\left(k_{0}\right)$ efficiency $\left(h_{k o}\right)$ can be determined by solving the given input-oriented CCR model.

$$
\begin{gathered}
\operatorname{Maxh}_{k 0}=\sum_{r=t}^{s} u_{r} Y_{r k 0} \\
\text { subject to } \sum_{i=1}^{m} v i X_{i k 0}=1 \\
\sum_{r=1}^{s} u_{r} Y_{r k}-\sum_{i=1}^{m} v_{i} X_{i k} \leq 0 \\
u_{r} v_{i} \geq \varepsilon>0, i=1, \ldots . . m, r=1, \ldots . . s, k=1, \ldots \ldots ., n
\end{gathered}
$$

It can be explained like, Xik represent the amount of input $\mathrm{i}$ for unit $\mathrm{k}$; While, Yrk explain the output $\mathrm{r}$ from unit $\mathrm{k}$, However, the weight of output $\mathrm{r}$ is denoted by ur, While the weight assigned to input $\mathrm{i}$ is denoted by vi . $\mathrm{n}=$ number of units; $\mathrm{s}=$ number of outputs; $\mathrm{m}=$ number of inputs; and $=$ small positive number. In order to compute the efficiency of any DMU, k0 can be solved by the twofold of (1). The second fold of (1) can be denoted as follows:

$$
\begin{aligned}
& \operatorname{Min} h_{k 0}=\theta-\varepsilon\left(\sum_{i=1}^{m} S_{\overline{i k o}}+\sum_{r=1}^{s} S_{\underset{t}{r k 0}}\right) \\
& \text { s.t. } \sum_{k=1}^{n} \lambda_{k} X_{i k}-\theta X_{i k o}+S_{\overline{i k o}}=0 \\
& \sum_{k=1}^{n} \lambda_{k} Y_{i k}-S_{\underset{+r k 0}{r k 0}}=Y_{r k 0} \\
& \lambda_{k}, S_{\overline{i k o}}, S_{\substack{t \\
r k 0}} \geq 0, i=1, \ldots . . m, r=1, \ldots . . s, k=1, \ldots, n \\
& \theta \text { Unconstrained. }
\end{aligned}
$$


A DMU k0 can be necessarily considered as efficient only when,

$$
h_{k 0}=\theta=1, S_{\overline{i k o}}=S_{\underset{+}{r k 0} 0}=0
$$

Therefore, A DMU with efficiency value of 1 will be considered as efficient and form the efficient frontier. $\operatorname{MaxDEA}{ }^{\circledR}$, has been utilized to compute the efficiencies from the well-defined inputs and outputs.

\section{Results}

The calculated efficiency scores as per DEA-CCR model relied on constant return to scale; they are presented in Table 1. In the present study, we took 30 listed insurance companies during 2015-2018. Average efficiency scores for the companies vary between 0.52632 (2015) to 0.61908 (2018). An upward trend in managerial efficiency can be seen easily. Remarkably, there were two companies, which have been efficient in each year during the study period, i.e.

Table 1: Input oriented CRS Efficiency Based on CCR and BCC

\begin{tabular}{|c|c|c|c|c|c|}
\hline \multicolumn{2}{|r|}{ DMUs } & \multicolumn{4}{|c|}{ Input-Oriented CRS Efficiency } \\
\hline NO & Name & 2018 & 2017 & 2016 & 2015 \\
\hline 1 & ACIG & 0.357 & 0.269 & 0.431 & 0.273 \\
\hline 2 & AICC & 0.229 & 0.219 & 0.274 & 0.298 \\
\hline 3 & AL ALAMIYA & 0.417 & 0.161 & 0.279 & 0.229 \\
\hline 4 & AL-AHLIA & 0.959 & 0.336 & 0.357 & 0.470 \\
\hline 5 & ALETIHAD & 0.860 & 0.659 & 0.696 & 1.000 \\
\hline 6 & ALLIANZ SF & 1.000 & 1.000 & 0.845 & 0.742 \\
\hline 7 & ALRAJHI TAKAFUL & 0.996 & 0.704 & 0.755 & 0.760 \\
\hline 8 & ARABIAN SHIELD & 0.491 & 0.295 & 0.550 & 0.527 \\
\hline 9 & ATC & 0.664 & 0.228 & 0.361 & 0.893 \\
\hline 10 & AXA COPRT. & 0.801 & 0.971 & 0.720 & 0.586 \\
\hline 11 & BUPA ARABIA & 1.000 & 1.000 & 1.000 & 1.000 \\
\hline 12 & BURUJ & 0.739 & 0.266 & 0.217 & 0.281 \\
\hline 13 & CHUBB & 0.161 & 0.128 & 0.137 & 0.118 \\
\hline 14 & ENAYA & 0.308 & 0.283 & 0.141 & 0.227 \\
\hline 15 & GULF GENERAL & 0.604 & 0.286 & 0.178 & 0.336 \\
\hline 16 & GULF UNION & 1.000 & 0.201 & 1.000 & 0.976 \\
\hline 17 & JAZIRA TAKAFUL & 1.000 & 1.000 & 1.000 & 1.000 \\
\hline 18 & MALATH INSURANCE & 0.254 & 0.405 & 0.139 & 0.227 \\
\hline 19 & MEDGULF & 0.835 & 0.569 & 1.000 & 0.999 \\
\hline 20 & METLIFE AIG ANB & 0.283 & 0.204 & 0.120 & 0.238 \\
\hline 21 & SABB TAKAFUL & 1.000 & 0.499 & 0.451 & 0.386 \\
\hline 22 & SAGR INSURANCE & 0.818 & 0.534 & 0.312 & 0.398 \\
\hline 23 & SAICO & 0.371 & 0.450 & 0.367 & 0.638 \\
\hline 24 & SALAMA & 0.765 & 0.647 & 0.675 & 1.000 \\
\hline 25 & SAUDI RE & 0.085 & 0.094 & 0.141 & 0.098 \\
\hline 26 & TAWUNIYA & 1.000 & 0.419 & 0.286 & 0.454 \\
\hline 27 & $\cup C A$ & 0.920 & 0.503 & 0.973 & 0.626 \\
\hline 28 & WAFA INSURANCE & 0.246 & 0.472 & 0.160 & 0.148 \\
\hline 29 & WALAA & 0.270 & 0.256 & 0.206 & 0.562 \\
\hline 30 & WATANIYA & 0.138 & 0.133 & 0.137 & 0.301 \\
\hline \multicolumn{2}{|c|}{ Mean Efficiency } & 0.619 & 0.619 & 0.440 & 0.464 \\
\hline
\end{tabular}


Bupa Arabia and Jazira Takaful. There is only one company (Allianze SF), which remains efficient in consecutive past two years. There are few companies, which have been relatively efficient over past few years.

Table 2 depicts the calculated efficiency scores as per DEA-VRS model relied on variable return to scale. The mean efficiency scores for the selected DMUs vary between 0.71409 (2015) to 0.80941 (2018). Upon the technical efficiency calculated on variable return to scale, three major players emerged, i.e. Bupa Arabia, Jazira Takaful and Tawuniya. 2018 has been the year where the majority of DMUs reached the frontier - out of 30 DMUs, 11 DMUs remain efficient, accounting for around 37 percent of overall population of samples taken for the study. It implied that management of around 37 percent companies is efficient in utilizing the inputs to yield the output in a highly efficient manner.

Table 2: Input oriented VRS Efficiency Based on CCR and BCC

\begin{tabular}{|c|c|c|c|c|c|}
\hline & DMUs & & ut-Orie & Efficie & \\
\hline NO & Name & 2018 & 2017 & 2016 & 2015 \\
\hline 1 & $A C I G$ & 0.913 & 0.573 & 1.000 & 0.650 \\
\hline 2 & AICC & 1.000 & 0.540 & 0.986 & 0.670 \\
\hline 3 & AL ALAMIYA & 1.000 & 0.652 & 0.955 & 0.595 \\
\hline 4 & AL-AHLIA & 1.000 & 0.477 & 0.358 & 0.710 \\
\hline 5 & ALETIHAD & 0.950 & 0.663 & 0.960 & 1.000 \\
\hline 6 & ALLIANZ SF & 1.000 & 1.000 & 0.864 & 1.000 \\
\hline 7 & ALRAJHI TAKAFUL & 1.000 & 0.713 & 0.768 & 0.798 \\
\hline 8 & ARABIAN SHIELD & 0.976 & 0.398 & 0.890 & 0.773 \\
\hline 9 & ATC & 0.701 & 0.298 & 0.418 & 0.906 \\
\hline 10 & AXA COPRT. & 1.000 & 0.996 & 1.000 & 0.750 \\
\hline 11 & BUPAARABIA & 1.000 & 1.000 & 1.000 & 1.000 \\
\hline 12 & BURUJ & 0.816 & 0.415 & 0.265 & 0.281 \\
\hline 13 & CHUBB & 0.483 & 0.502 & 0.480 & 0.277 \\
\hline 14 & ENAYA & 0.313 & 0.594 & 0.452 & 1.000 \\
\hline 15 & GULF GENERAL & 0.678 & 1.000 & 0.261 & 0.336 \\
\hline 16 & GULF UNION & 1.000 & 0.345 & 1.000 & 1.000 \\
\hline 17 & JAZIRA TAKAFUL & 1.000 & 1.000 & 1.000 & 1.000 \\
\hline 18 & MALATH INSURANCE & 0.521 & 0.410 & 0.141 & 0.237 \\
\hline 19 & MEDGULF & 0.838 & 1.000 & 1.000 & 1.000 \\
\hline 20 & METLIFE AIG ANB & 0.944 & 0.622 & 1.000 & 1.000 \\
\hline 21 & SABB TAKAFUL & 1.000 & 0.888 & 1.000 & 0.527 \\
\hline 22 & SAGR INSURANCE & 0.900 & 0.590 & 0.349 & 0.436 \\
\hline 23 & SAICO & 0.724 & 0.546 & 0.379 & 0.644 \\
\hline 24 & SALAMA & 0.842 & 0.698 & 0.686 & 1.000 \\
\hline 25 & SAUDI RE & 0.202 & 0.125 & 0.213 & 0.175 \\
\hline 26 & TAWUNIYA & 1.000 & 1.000 & 1.000 & 1.000 \\
\hline 27 & UCA & 0.921 & 0.735 & 1.000 & 0.708 \\
\hline 28 & WAFA INSURANCE & 0.709 & 0.502 & 0.729 & 0.589 \\
\hline 29 & WALAA & 0.425 & 0.310 & 0.535 & 1.000 \\
\hline 30 & WATANIYA & 0.425 & 0.246 & 0.398 & 0.360 \\
\hline \multicolumn{2}{|c|}{ Mean Efficiency } & 0.809 & 0.628 & 0.703 & 0.714 \\
\hline
\end{tabular}


Table 3: Average yearly input oriented efficiencies

\begin{tabular}{|c|c|c|c|}
\hline YEAR & $\begin{array}{c}\text { Mean Efficiency } \\
\text { (Pure) CRS }\end{array}$ & $\begin{array}{c}\text { Mean Efficiency } \\
\text { (Technical) VRS }\end{array}$ & $\begin{array}{c}\text { Mean Efficiency } \\
\text { (Scale) }\end{array}$ \\
\hline 2018 & 0.619 & 0.809 & 0.765 \\
\hline 2017 & 0.440 & 0.628 & 0.700 \\
\hline 2016 & 0.464 & 0.703 & 0.660 \\
\hline 2015 & 0.526 & 0.714 & 0.737 \\
\hline
\end{tabular}

The calculated mean efficiency has been presented in Table 3. The process of disintegration of technical efficiencies into scale and pure technical efficiencies helps to get the insight into the main sources of inefficiencies (Malik, 2009). Notably, the variations among the technical, scale and pure efficiencies during the study period are not wider. It varies between 44 to 62 percent, 63 to 81 percent and 66 to 76 percent among the technical, pure and scale efficiencies, respectively.

In this paper, we have also tried to map the distance between the two calculated technical efficiencies. It is assumed that minimal distance between the two comparative values is a better indicator of computed efficiency values (Hwang \& Tong-Liang, 2006). The converse picture presents the opposite view of this. Figure 1 depicts that DMU- 1 to 3, 13 to 15 and 20 are relatively distant in their values calculated on two different scales. It indicates the substantive difference amongst the two efficiencies. While other DMU's efficiency, which shows the proximity with each other, indicate the reliability of results.

\section{Discussions}

Generally, the efficiency of firms is related to the optimization of input in producing the outputs in a given timeframe. This research has adopted the same approach to find out the managerial efficiency of insurance firms in KSA. Our study utilizes the input oriented technical efficiency by applying the Data Envelopment Analysis (DEA). The assumption adopted for the current study focuses on the managerial aspects of companies, "How efficiently a company utilizes the managerial resources in generation of revenues and profit". The DEA tool is considered the most appropriate for efficiency studies. The CCR model by Charnes et al. (1978) and the BCC model by Banker et al. (1984) are regarded as the widely-used and best-known DEA models (Barros et al., 2011; Hwang \& Tong-Liang, 2006). Therefore, we have utilized the CCR and BCC models based on CRS and VRS to calculate the pure and technical efficiencies of listed insurance companies in KSA (see Figure 1).

The results discussed in the previous section indicate that three firms, namely, Bupa Arabia, Jazira Takaful and

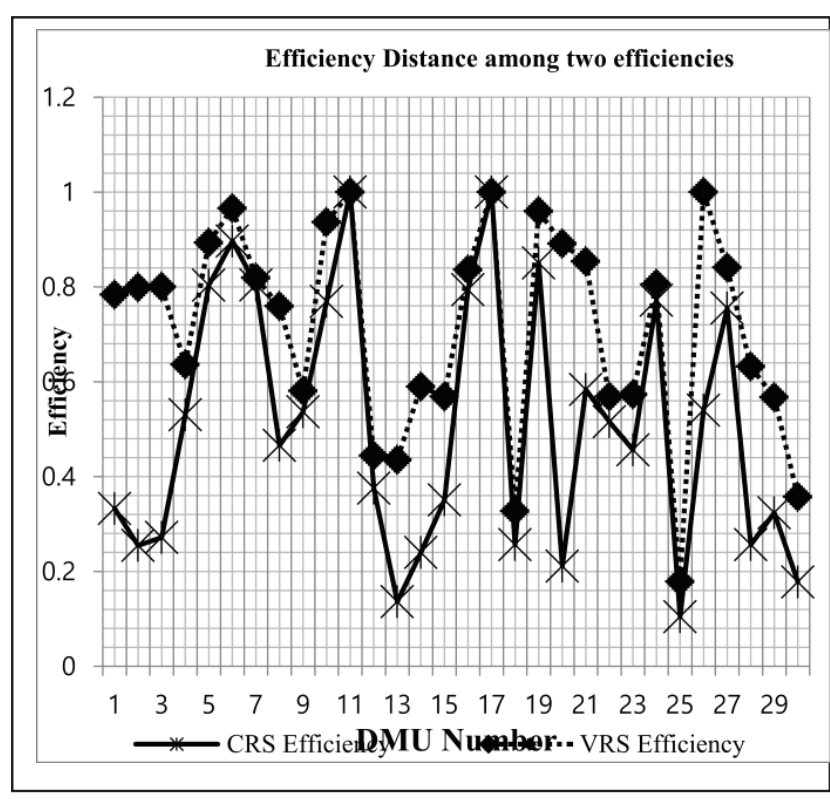

Figure 1: Efficiency Distance among two efficiencies

Tawuniya, have emerged as the market leader in terms of managerial efficiency, and could be benchmarked by others companies operated in the market. A good amount of significant points have emerged from the current research. Firstly, the results resemble (or are in line with) other DEAbased efficiency studies in the same context like, Benyoussef and Hemrit (2019) and Almulhim (2019) who took different sets of inputs and outputs. Bupa Arabia has emerged as the undisputed market leader in terms of managerial and other efficiencies. It is evident from the current study, while comparing with others, that DMU's except Bupa Arabia, which is on the frontiers since long back, others are depicting the increasing return to scale. Therefore, the management must pay much attention to maintain the momentum. It is astonishing that, as per the study of Akhtar Muhammad (2018), the companies which were efficient before 2015 are found to be no more efficient and the efficiency frontier has been occupied by some new players like, Bupa Arabia, Tawuniya and Al- Jazira Takaful. Therefore, the current management of these companies must take advantage of 
their competencies developed in various field and must focus on further development. The companies, which are still among the laggards, must identify their grey areas and focus on developing a sustainable competitive advantage.

DEA comes top amongst the highly-used tools applied in efficiency studies. There are several additions and models that have already been developed under DEA. A two-stage DEA model suggested by Seiford and Zhu (1999) and later applied and tested by Chen (2002); Hwang and TongLiang (2006); Zhu (2000) could overcome the limitations associated with one-stage DEA methods.

\section{Conclusions}

This study investigated the managerial efficiency of insurance companies listed in the Saudi stock exchange, Tadawul. Present research contributes to DEA and managerial efficiency by identifying the clear-cut market leader in terms of managerial efficiency. Consistent with recent research on efficiency of insurance companies in KSA (Akhtar Muhammad, 2018; Almulhim, 2019; Benyoussef \& Hemrit, 2019; Hemrit, 2020), our findings earmarked the companies that are highly efficient in managerial efficiency. The major take-away from the current study could be summarized as follows. Firstly, like other efficiencies studies conducted on Saudi insurance sectors in managerial efficiency domain, there are certain players that emerged as highly efficient in managerial aspects, but were no efficient in the earlier studies (Akhtar Muhammad, 2018; Almulhim, 2019). Secondly, in the study there is no firm that has the zero (0) efficiency or a negative efficiency. Thirdly, the firms that remain efficient during the entire period of study are only three. Remarkably, for some firms, the efficiency patterns follow the ups and down trend on the line, which indicates that firms are not entirely inefficient. Their managerial resources have the capacities to achieve the full efficiency at certain point in time. The companies, which remain efficient on CRS scale, have also remained efficient on the VRS scale as well.

Therefore, it can be concluded that the majority of insurance firms operating in KSA are found to be efficient on managerial efficiency scale. And three firms remain the leaders on the efficiency frontier of the managerial efficiency. Admittedly, the study is not free from limitations. The major limitation is the inadequacy of input and outputs as only two of each has been taken for the analysis. The implications of advanced DEA models could have emerged with better efficiency score. Therefore, in future, researchers can investigate the managerial efficiency with more advanced models of DEA.

\section{References}

Agasisti, T. (2014). Measuring the "managerial" efficiency of public schools: a case study in Italy. International Journal of Educational Management, 28(2), 120-140. doi:10.1108/IJEM02-2013-0032

Akhtar Muhammad, H. (2018). Performance analysis of Takaful and conventional insurance companies in Saudi Arabia. Benchmarking: An International Journal, 25(2), 677-695. doi:10.1108/BIJ-01-2017-0018

Al-Amri, K. (2015). Takaful insurance efficiency in the GCC countries. Humanomics, 31(3), 344-353. doi:10.1108/H-05-2014-0039

Ali, A., \& Tausif, M. R. (2019). Assessing profitability and growth of insurance sector in Saudi Arabia: using financials and tangibles. Humanities \& Social Sciences Reviews, 7(6), 617624.

AlKhathlan, K., \& Malik, S. A. (2010). Are Saudi banks efficient? Evidence using data envelopment analysis (DEA). International Journal of Economics and Finance, 2(2), 53-58.

Almulhim, T. (2019). Analysis of Takaful vs. Conventional insurance firms' efficiency: Two-stage DEA of Saudi Arabia's insurance market. Cogent Business \& Management, 6(1), 1633807. doi:10.1080/23311975.2019.1633807

An, S. B., Ryu, Y. R., \& Yoon, K. C. (2020). Managerial Centrality and Shared Growth: Evidence from Korean Service Corporations' Financial Records. Journal of Asian Finance, Economics and Business, 7(1), 249-257. https://doi.org/10.13106/jafeb.2020. vol7.no1.249

Avkiran, N. K., \& Rowlands, T. (2008). How to better identify the true managerial performance: State of the art using DEA. Omega, 36(2), 317-324. doi:https://doi.org/10.1016/j. omega.2006.01.002

Banker, R. D., Charnes, A., \& Cooper, W. W. (1984). Some models for estimating technical and scale inefficiencies in data envelopment analysis. Management science, 30(9), 1078-1092.

Barros, C. P., Botti, L., Peypoch, N., \& Solonandrasana, B. (2011). Managerial efficiency and hospitality industry: the Portuguese case. Applied Economics, 43(22), 2895-2905. doi:10.1080/00036840802600145

Barros, C. P., Dumbo, S., \& Wanke, P. (2014). Efficiency determinants and capacity issues in Angolan insurance companies. South African Journal of Economics, 82(3), 455467.

Benyoussef, S., \& Hemrit, W. (2019). Measuring the relative efficiency of insurance companies in Saudi Arabia: The case study of Takaful vs cooperative industries. Cogent Economics \& Finance, 7(1), 1590818. doi:10.1080/233220 39.2019.1590818 
Borges, M. R., Nektarios, M., \& Barros, C. P. (2008). Analysing the Efficiency of the Greek Life Insurance Industry. European Research Studies, 11(3).

Charnes, A., Cooper, W. W., \& Rhodes, E. (1978). Measuring the efficiency of decision making units. European journal of operational research, 2(6), 429-444.

Chen, C. F. (2007). Applying the stochastic frontier approach to measure hotel managerial efficiency in Taiwan. Tourism Management, 28(3), 696-702.

Chen, T. Y. (2002). Measuring operation, market and financial efficiency in the management of Taiwan's banks. Services Marketing Quarterly, 24(2), 15-27.

Choi, J., \& Cho, D. (2019). Risk-Seeking Behavior of Financial Institutions due to Deposit Insurance: Evidence from Korea. Journal of Asian Finance, Economics and Business, 6(1), 8389. http://doi.org/10.13106/jafeb.2019.vol6.no1.83

Cummins, J. D., \& Weiss, M. A. (2013). Analyzing firm performance in the insurance industry using frontier efficiency and productivity methods. In Handbook of Insurance (pp. 795861): Springer.

Eling, M., \& Luhnen, M. (2010). Efficiency in the international insurance industry: A cross-country comparison. Journal of Banking \& Finance, 34(7), 1497-1509.

Haque, M. I. a., \& Sultan, Z. A. (2019). A structural equation modeling approach to validate the dimensions of SERVPERF in insurance industry of Saudi Arabia. Management Science Letters, 09(04), 495-504.

Hemrit, W. (2020). Determinants driving Takaful and cooperative insurance financial performance in Saudi Arabia. Journal of Accounting \& Organizational Change, [Online First], doi: https://doi-org.sdl.idm.oclc.org/10.1108/JAOC-03-2019-0039

Hwang, S.-N., \& Tong-Liang, K. (2006). Measuring Managerial Efficiency in Non-Life Insurance Companies: An Application of Two-Stage Data Envelopment Analysis. International Journal of Management, 23(3), 699-720.

Ilyas Ashiq, M. (2019). An empirical investigation of efficiency and productivity in the Indian non-life insurance market. Benchmarking: An International Journal, 26(7), 2343-2371. doi:10.1108/BIJ-01-2019-0039

Kaffash, S., Azizi, R., Huang, Y., \& Zhu, J. (2019). A survey of data envelopment analysis applications in the insurance industry 1993-2018. European Journal of Operational Research. https://doi.org/10.1016/j.ejor.2019.07.034

Mandal, S. (2014). A DEA-investigation of efficiency of the Indian general insurance during recession. Journal of Advances in Management Research, 11(1), 115-136. doi:10.1108/JAMR07-2012-0030.
Masud, M. M., Rana, M. S., Mia, M. A., \& Saifullah, M. K. (2019). How Productive Are Life Insurance Institutions in Malaysia? A Malmquist Approach. Journal of Asian Finance, Economics and Business, 6(1), 241-248. http://doi.org/10.13106/ jafeb.2019.vol6.no1.241

Naushad, M. (2019a). Arrays of Intellectual Capital among SMEs in Saudi Arabia. Journal of Advanced Research in Dynamical and Control Systems, 11(Special Issue-8), 2175-2180.

Naushad, M. (2019b). Intellectual capital and financial performance of Sharia-compliant banks in Saudi Arabia. Banks and Bank Systems, 14(4), 1-9.

Naushad, M., \& Malik, S. A. (2015). Corporate governance and bank performance: a study of selected banks in GCC region. Asian Social Science, 11(9), 226.

Nourani, M., Devadason, E. S., Kweh, Q. L., \& Lu, W.-M. (2017). Business excellence: the managerial and valuecreation efficiencies of the insurance companies. Total Quality Management \& Business Excellence, 28(7-8), 879-896. doi:10. 1080/14783363.2015.1133244

Pacheco, R., \& Fernandes, E. (2003). Managerial efficiency of Brazilian airports. Transportation Research Part A: Policy and Practice, 37(8), 667-680.

Rao, A. (2010). Analysis of managerial efficiency in insurance sector in the UAE: an emerging economy. International Journal of Managerial Finance, 6(4), 329-343. doi:10.1108/17439131011074477

Rahman, A. M. (2018). Voluntary Insurance for Ensuring RiskFree On-the-Go Banking Services in Market Competition: A Proposal for Bangladesh. Journal of Asian Finance, Economics and Business, 5(1), 17-27. http://dx.doi.org/10.13106/ jafeb.2018.vol5.no1.17

Seiford, L. M., \& Zhu, J. (1999). Profitability and marketability of the top 55 US commercial banks. Management Science, 45(9), 1270-1288.

Shyu, J., \& Chiang, T. (2012). Measuring the true managerial efficiency of bank branches in Taiwan: A three-stage DEA analysis. Expert Systems with Applications, 39(13), 1149411502. doi:https://doi.org/10.1016/j.eswa.2012.04.005

Sulphey, M., \& Naushad, M. (2019). The position of intellectual capital among Saudi banks. Marketing and Management of Innovations, 10(4), 11-21.

Yang, C., \& Liu, H.-M. (2012). Managerial efficiency in Taiwan bank branches: A network DEA. Economic Modelling, 29(2), 450-461.

Zhu, J. (2000). Multi-factor performance measure model with an application to Fortune 500 companies. European Journal of Operational Research, 123(1), 105-124. 